\title{
Corporate Financial Distress: Analysis of Indian Automobile Industry
}

\author{
N.C. Shilpa ${ }^{1 *}$ and M. Amulya ${ }^{2}$ \\ ${ }^{1}$ Research Scholar (UGC-JRF), B. N. Bahadur Institute of Management Sciences, University of Mysore, \\ Manasagangothri, Mysore, India \\ ${ }^{2}$ Assistant Professor, B. N. Bahadur Institute of Management Sciences, University of Mysore, Manasagangothri, \\ Mysore, India
}

\begin{abstract}
Financial distress leads to bankruptcy of firm which features systemic impact on both macro and micro economy of the country. Industry characteristics too play an important role in endurance of firm and successively with its financial strategies. Compulsion to evaluate the financial strength of firm is a significant aspect for both Internal and External stakeholders, especially creditors. Information that firm is approaching distress can set out managerial actions to anticipate problems before they occur. Drastic changes in automobile policies in India have mixed effects on Automobile Industry. This paper is an attempt to evaluate the financial health of automobile industry in India. Automobile industry has been classified into four categories based on products namely Passenger car, commercial vehicles, motorcycle/ mopeds and scooters \& 3-wheelers manufacturers. The Altman Z score model developed for manufacturing firms has been applied for ten years (2007 to 2016) during which period features Automotive Mission Plan framed by Government of India. The study reveals that commercial vehicle manufactures are in intermediate area of financial distress and calls for agile action.
\end{abstract}

Keywords: Financial Distress, Bankruptcy, Stakeholders, Altman Z Score Model, Intermediate Area

\section{Introduction}

The development of India as open economy is much evident from the strong signals of uncertainty in macroeconomic issues. Firm environment dynamically, and often unexpectedly, evolves with changing macroeconomic conditions. Industry characteristics also have major influence on financial strategies. Operating in competitive world to produce positive results without being strategic is next to impossible. Firm acting in the interest of shareholders strive to maximize the market value of equity. Accordingly, investment and financing activities are planned.

Besides, management should continuously assess their financial position to know about cost of financial distress. Otherwise firm could be thrown out of business especially during financial crisis. Altman Z-score model helps to identify the firm as financially distressed which passes through different stages before going bankrupt.

Financial distress is defined as an inability of the company to meet its current financial obligations. It is directly related to the firm's leverage decision. Economic distress, however, means troubles originating from the firm's operational inefficiencies. Hence all-equity firm can only be economically distressed, but can never be financially distressed because there are no creditors involved. In automobile industry, which is capital intensive, it is uncommon to find all-equity firms. The prime trouble that causes financial distress for this industry is the existence of high leverage.

*Email: shilpa_nc86@yahoo.co.in 
Aftermath of economic liberalization in 1990s, Indian Automobile Industry has witnessed tremendous market growth. Government of India has taken several initiatives to maintain high rate of growth and to retain the attractiveness of Indian market. Further to enhance the competitiveness of Indian firms, the Government through the Development Council on Automobile and Allied Industries constituted a team to draw up a ten year Mission Plan for the Indian Automotive Industry.

As a consequence the Automotive Mission Plan 20062016 was released in 2007. It had vision that India should emerge as a destination of choice in the world for design and manufacture of automobiles and auto components with output reaching a level of $\$ 145$ billion accounting for more than 10 per cent of the GDP and providing additional employment to 25 million people by 2016.During 2006 -2011 all vehicle segments recorded a Compound Annual Growth Rate (CAGR) in excess of $10 \%$. However, from financial year 2011 the slowdown in global economy coupled with weakness in the fundamental growth drivers has resulted in decline in growth across vehicle segments except for two wheelers, which posted a CAGR of $4.6 \%$.

Today the Automobile industry accounts for 7.1 per cent of the country's Gross Domestic Product (GDP). Industry has registered incremental employment of 19 million since 2006.

\begin{tabular}{|c|c|}
\hline \multicolumn{2}{|c|}{ Domestic Market Share for 2015-16 in \% } \\
\hline Passenger Vehicles & 14 \\
\hline Commercial Vehicles & 3 \\
\hline Three Wheelers & 3 \\
\hline Two Wheelers & 80 \\
\hline
\end{tabular}

Source: Society of Indian Automobile Manufacturing (SIAM), 2015-16

This paper is an attempt to evaluate the financial health of automobile industry in India. It focuses on accounting-based versions of the Z-Score models. The paper proceeds as follows. Section 2 elaborates on literature review related to methods used to analyse financial distress. Section 3 provides conceptual framework, research objectives and elaborates on the statistical methodology. Section 4 provides data analysis and interpretation. The last section provides summary and concluding remarks.

\section{Literature Review}

Beaver (1966) was the initial researchers to use univariate analysis to point out that financial distress. He claimed that by using cash-flow to total-debt ratio or likelihood ratio, one can forecast failure before five years.

Altman (1968) was seminal work which proposed that ratio analysis was not robust technique to analyse financial distress of firm. Paper stressed on the fact that multivariate framework is necessary which was proved by the model suggested.

Trieschmann et al; (1973) expended multiple discriminant analysis to discover financial distress risk associated with insurance companies. The model developed was able to classify correctly 49 out of 50 firms included in the study. One financially healthy firm was assorted as being distress while two of the distress firms were classified as belonging to the financially healthy group.

Moyer (1977) compared univariate analysis with discriminant analysis to find which model is superior in categorising firms as financially healthy and distresses. The paper notes the success of discriminant analysis with span of two years prior to bankruptcy but declines considerably for longer lead times.

Bulow et al; (1978) investigated the conditions which will lead to bankruptcy. The model directs that nexus of contracts with the firm explicate conflict of interest between the stakeholders. They illustrate the prominent role of liquid assets and the maturity structure of the debt in avoiding bankruptcy.

Altman (1983) posited that to develop model which can predict bankruptcy, it would be exemplary to employ sample firms from corresponding bankrupt group. He further suggests that researcher should collect data of bankrupt and non-bankrupt firms' separately when concerned with specific industry.

Gilson (1989) analysed the relationship between senior management turnovers with respect to financial distress. They found that if there is sign of default risk, firms experience turnover in senior management and radical 
changes are originated by creditors. On the other hand, these managers find difficulty in getting employed by other listed firms for at least three years.

Opler et al; (1990) found that during the industry downturn, highly leveraged firms are susceptible to financial distress due to contraction in sale. They claim that adverse effects of leverage are more prominent in concentrated industries, firms with specialized products and firms which spend more in research and development because of indirect costs.

John (1993) employs Tobin's q ratio (equal to market value/replacement cost) as a proxy for the loss of going-concern value in asset sales and premature liquidations associated with financial distress. He strongly opines that there is positive relationship between corporate liquidity and financial distress costs. However, the relationship between corporate leverage and financial distress costs is established to be negative.

Kahya et al; (1999) uses CUSUM model which is an extension for discriminant analysis. They claim that CUSUM model has ability to track bad performances for long period when compared to good performances. Hence the model gives an alarm to the financial analyst who can then undertake a closer investigation and assessment of firm.

Altman (2000) amends Z-Score model to develop ZETA model for appraising bankruptcy risk of firms. It is based on data more relevant to current conditions and to a larger number of industrial firms. The potential applications of the ZETA bankruptcy identification model are to assure credit worthiness of firms for financial and non-financial institutions, identification of undesirable investment risk for portfolio managers and individual investors and to aid in more effective internal and external audits of firms with respect to going-concern considerations, among others.

Grice et al; (2001) seeks to validate the application of $\mathrm{Z}$-score model current scenario. They tested the model for predicting bankruptcy of non-manufacturing firms as it was originally developed for manufacturing firms. They also examined whether the model was useful for predicting financial stress other than bankruptcy. They established the fact that the model was more subtle inestimating bankruptcy of manufacturing firms compared to non-manufacturing firms. Also the model was insensitive to predict other forms of distress.

Platt et al; (2002) analysed automotive supplier industry and suggested that the early warning model successfully discriminated between distressed firms and healthy firms. They claimed that model should include all firms within a population; otherwise it could result in choice-based sample bias.

Chava et al; (2004) paper scrutinize the dominance of Shumway's model (2001) over Altman's model (1968) and Zmijewski's in forecasting bankruptcy by collecting extensive data. They substantiate the fact that industry groupings will remarkably influence the bankruptcy risk rate in the model.

Kwak et.al., (2005) employed data mining technique called Multiple Criteria Linear Programming (MCLP) to identify the bankrupt firms. The outcome was compared with Altman's multi discriminant model and Ohlson's logit model. They claim that MCLP model has superior prediction rate than Altman model and similar result as Ohlson's model.

Dawkins et al., (2007) analysed the fluctuations in share price after firm has filled bankruptcy. They employed event study methodology and controlled firms' financial condition by using Altman's z-score model. It was observed that there was increase in share price even when firm filed bankruptcy because of prevailing bull market conditions. Huge transactions were commanded by large traders post bankruptcy filing as investors were abnormally optimistic.

Fich et al; (2008) investigated the association between firm's governance practices and capability to avoid bankruptcy. They predicted the bankruptcy of firms using Altman's Z-score model along with interest coverage ratio. It was found that during firm distress situation bad governance will misrepresent accounting information and will not have ability to handle the situation. This often occurs if they are independent boards than inside directors. 
Agarwal et al; (2008) compared the accuracy of predicting bankruptcy using market base model with accounting Z-score model. It was found that neither of the models had adequate information for predicting failure as they were unique. However, it was concluded that accounting based models account for credit risk since accounting statements capture performance for several years.

Shen, et al; (2010) compares logit model with robust logit developed based on Altman's z-score. They found robust logit model was superior even when the sample included statistical outliers (firms that are doing extremely good or bad). However, robust logit model was vigorously allocating firms as default.

Ray (2011) evaluates financial health of automobile industry during from 2003 to 2010 in India using Z-score model. The multiple discriminant framework has depicted moderate picture. The Z-score lies within "Grey Zone" suggesting credit risk associated with the industry. The study indicates alarming situation where $\mathrm{Z}$ score is declining after global recession hits Indian economy (2007).

Chen et al., (2012) analysed the effect of pricing of corporate debt due to "unionized workers" in financially distressed and healthy firms. They employed five different indicators including Altman's Z-score model to identify if firm is in distress. Using all five alternative models of distress, it was found that "unionized workers" and Distress has negative relation which is statistically significant. This is because labour unions try to shield creditor's wealth even though they support firm policy to reduce creditors' wealth during distress.

Singhal et al; (2013) examines the relationship between bankruptcy and diversification strategy of firms. Altman Z-score used to represent the likelihood of bankruptcy which is highly correlated with leverage. It was found that focused firms are more likely to go bankrupt than diversified firms.

$\mathrm{Li}$ (2014) explores the application of Altman's bankruptcy model in construction industry. The original five set variable is expanded to 14 set variable. The conclusion drawn is that Altman's model stands both valid and effective in context of bankruptcy prediction for sample selected.

Celli (2015) found that the Z-score degree of reliability is relatively high and still works quite adequately in predicting listed industrial company failure in Italy. It proved a precious tool in the detection of company operating and financial difficulties up to 3 years before the default.

Altman et al. (2016) re-examined the original version of the Z-Score model using data of different countries. They re-estimated values using another statistical method and additional variables to assess the affect of classification performance when the data are heterogeneous. The evidence indicates that the original $Z$-Score model executes well at an international context till date.

The conclusion from the review is that although the $Z$-Score model was developed nearly five decades ago and many alternative failure prediction models exist, the $Z$-Score model continues to be used worldwide as a main or supporting tool for bankruptcy or financial distress prediction and analysis; both in research and in practice. This paper focuses on accounting-based versions of the Z-Score models, which even though they are occasionally outperformed by other models, do not rely on market data.

\section{Conceptual Framework}

Altman (1968) built upon univariate findings and put together respective measures into a meaningful predictive model called Multiple Discriminant Analysis (MDA). He classified those variables into five standard ratios categories: liquidity, leverage, profitability, solvency, and activity ratios. The final discriminant function estimated by Altman (1968) for publicly traded firms is as follows:

$$
\begin{gathered}
\mathrm{Z}=0.012 * \mathrm{X} 1+0.014 * \mathrm{X} 2+0.033 * \mathrm{X} 3+0.006 * \mathrm{X} 4+ \\
0.999 * \mathrm{X} 5
\end{gathered}
$$

Where,

$\mathrm{X} 1$ = working capital/total assets - indicating liquidity ratio. 
$\mathrm{X} 2$ = retained earnings/total assets - indicating leverage ratio.

$\mathrm{X} 3$ = earnings before interest and taxes/total assets indicating profitability ratio.

$\mathrm{X} 4=$ market value equity/book value of total liabilities - indicating solvency ratio

$\mathrm{X} 5=\mathrm{sales} /$ total assets - indicating activity ratio.

\subsection{Research Objectives}

- To examine the financial health of automobile industry in India.

- To apply Altman's Z-score model to predict the financial distress in automobile industry in India.

\subsection{Methodology}

This study is descriptive in nature. Automobile industry has been classified into four categories such as passenger car, commercial (Light and Heavy), Motorcycles/ Mopeds and Scooters and 3-Wheelers manufacturers.

\subsection{Data Collection}

The consolidated accounting data for each category under automobile industry was collected from capital line database. The financial data collected are annual and collected for period of ten years (2007-2016). The number of firms varies in each annual year because of bankruptcy.

\section{Data Analysis}

The discriminant function is applied to data collected for each category.

$$
\mathrm{Z}=1.2 * \mathrm{X} 1+1.4 * \mathrm{X} 2+3.3 * \mathrm{X} 3+0.6 * \mathrm{X} 4+1.0 * \mathrm{X} 5
$$

If the $\mathrm{Z}$-score calculated using the data is more than 2.99 , it is considered to be financially healthy. If Uncertain with scores between 1.81 and 2.99 are considered to be in grey area. They can be further classified into Low default probability $(2.675<\mathrm{Z}<2.99)$ and Middle - high default probability (if $1.81<\mathrm{Z}<2.675$ ) and finally if $\mathrm{Z}$-score is less than 1.81 , firm is at major default risk.

\subsection{Results and Interpretation}

Table 1 below shows ratio $\mathrm{X} 1$ = working capital/total assets in percentage terms. A negative net working capital will arise when current liabilities exceed current assets i.e. there is no working capital, but there is a working capital deficit. On the other hand, high working capital indicates that either firm has too much inventory or not actively managing investment activities. If the firm cannot maintain a satisfactory level of working capital, it is likely to become insolvent and may even be pushed into bankruptcy.

From the below table, it is evident that passenger car manufacturers are relatively stabilized in managing working capital. Commercial vehicle manufacturers had high working capital in past a year $(27.26 \%)$ which is now becoming negative. Motorcycles/mopeds and Scooters and 3-wheeler manufacturers had negative working capital in past $(-47.24 \%$ and $-57.49 \%$ respectively) which has enhanced the usage of working capital with growing volume of operational efficiency.

Table 2 below shows $\mathrm{X} 2$ = retained earnings/total assets in percentage. Firm may wish to distribute profit to stockholders as dividends to please. But firm may also need to keep its cash for operations and to create growth opportunities. The above options are exclusively subjected to management decision and firm's history of dividend policy. Besides, lenders may restrict such activities to assure that a firm maintains a minimum level of stockholders' equity. The ratio appears to be moderate in all categories and high in scooters and 3-wheelers category. The ratio less than $100 \%$ (in case of all four categories) indicates that growth might not be sustainable as it is financed through debt. In our study, the trend is gradually increasing which means automobile firms are able to generate adequate reserves for future business aspect.

Table 1. X1 liquidity measure in percentage

\begin{tabular}{ccccc}
\hline Year & Passenger cars & $\begin{array}{c}\text { Commercial } \\
\text { Vehicles }\end{array}$ & $\begin{array}{c}\text { Motorcycles / } \\
\text { Mopeds }\end{array}$ & $\begin{array}{c}\text { Scooters and } \\
\text { 3-Wheelers }\end{array}$ \\
\hline 2007 & 22.17 & 27.26 & -7.66 & -57.49 \\
2008 & 14 & 9.21 & -10.47 & -22.5 \\
2009 & 16.55 & 2.95 & -14.74 & -15.52 \\
2010 & 8.95 & -7.87 & -21.44 & -33.6 \\
2011 & 9.81 & 0.13 & -47.24 & -29.56 \\
2012 & 11.52 & -2.13 & -19.71 & -17.17 \\
2013 & 6.49 & -2.81 & -16.23 & -13.97 \\
2014 & 6.21 & -9.16 & -18.22 & -18.11 \\
2015 & 3.15 & -1.74 & -3.72 & -9.98 \\
2016 & 4.37 & -1.18 & -2.81 & 0.31 \\
\hline
\end{tabular}


Table 2. X2 age and leverage measure in percentage

\begin{tabular}{ccccc}
\hline Year & Passenger cars & $\begin{array}{c}\text { Commercial } \\
\text { Vehicles }\end{array}$ & $\begin{array}{c}\text { Motorcycles / } \\
\text { Mopeds }\end{array}$ & $\begin{array}{c}\text { Scooters and } \\
\text { 3-Wheelers }\end{array}$ \\
\hline 2007 & 44.48 & 59.15 & 71.69 & -34.31 \\
2008 & 48.93 & 56.21 & 74.99 & 34.02 \\
2009 & 41.11 & 50.46 & 63.9 & 38.32 \\
2010 & 48.94 & 47.35 & 50.62 & 62.51 \\
2011 & 56.03 & 50.19 & 52.96 & 74.87 \\
2012 & 48.79 & 51.02 & 51.37 & 70.04 \\
2013 & 50.37 & 44.4 & 57.72 & 76.3 \\
2014 & 40.43 & 42.97 & 72.71 & 80.05 \\
2015 & 43.73 & 29.7 & 71.1 & 80.48 \\
2016 & 39.6 & 34.85 & 61.65 & 81.85 \\
\hline
\end{tabular}

Table 3 shows $\mathrm{X} 3$ = earnings before interest and taxes/ total assets in percentage terms. It is indicator of firm's assets, independent of any tax or interest on debt. The ratio measures efficiency of firm's assets. The ultimate objective of the firm is to maximize shareholder's wealth which is directly related to earning power of assets. The ratio indicates good sign for Motorcycles/ Mopeds and Scooters and 3-wheelers category but has declining movement. However the ratio is steeply declining for a commercial vehicle manufacturer which is dangerous trend (2.68\% in the year 2015).

Table 4 shows $\mathrm{X} 4=$ market value of equity/book value of total liabilities in percentage terms. The market value of equity is the total market value of all of the stock, both preferred and common stock The book value of liabilities is the total value of liabilities both long term and current. The ratio shows how much the firm's assets can decline in value with increasing liabilities, before the liabilities exceed the assets. In our study, ratio especially in year 2011 was very low for all four categories. Decrease in the ratio was an indication that firm's share price was relatively low and cost of debt was relatively high. The adept matter of firms to quickly react is evident in the consecutive year 2011 . The commercial vehicle manufacturers have sluggish trend in adopting changes in financial structure.

Table 5 shows $\mathrm{X} 5=$ sales/total assets in percentage terms also known as capital turnover ratio. It depicts the sales generating ability of the firm's assets. Sometimes the ratio decreases steeply for a given period as compared
Table 3. X3 productivity measure in percentage

\begin{tabular}{ccccc}
\hline Year & Passenger cars & $\begin{array}{c}\text { Commercial } \\
\text { Vehicles }\end{array}$ & $\begin{array}{c}\text { Motorcycles / } \\
\text { Mopeds }\end{array}$ & $\begin{array}{c}\text { Scooters and } \\
\text { 3-Wheelers }\end{array}$ \\
\hline 2007 & 28.95 & 29.71 & 37.41 & 29.66 \\
2008 & 24.14 & 23.29 & 37.7 & 44.21 \\
2009 & 12.6 & 11.18 & 37.81 & 38.89 \\
2010 & 25.5 & 15.63 & 52.82 & 64.55 \\
2011 & 25.65 & 14.4 & 45.88 & 81.94 \\
2012 & 20.57 & 15 & 46.99 & 63.85 \\
2013 & 20.15 & 9.13 & 41.98 & 52.05 \\
2014 & 15.95 & 7.1 & 49.73 & 48.26 \\
2015 & 21.21 & 2.68 & 44.75 & 40.23 \\
2016 & 20.23 & 7.07 & 41.42 & 45.24 \\
\hline
\end{tabular}

Table 4. X4 solvency measure in percentage terms

\begin{tabular}{ccccc}
\hline Year & Passenger cars & $\begin{array}{c}\text { Commercial } \\
\text { Vehicles }\end{array}$ & $\begin{array}{c}\text { Motorcycles / } \\
\text { Mopeds }\end{array}$ & $\begin{array}{c}\text { Scooters and } \\
\text { 3-Wheelers }\end{array}$ \\
\hline 2007 & 28.64 & 4.5 & 8.29 & 77.66 \\
2008 & 22.07 & 3.74 & 7.31 & 15.95 \\
2009 & 21.02 & 2.52 & 13.6 & 13.6 \\
2010 & 21.44 & 4.61 & 26.19 & 6.77 \\
2011 & 14.93 & 3.55 & 6.4 & 9.75 \\
2012 & 15.72 & 4 & 18.71 & 19.2 \\
2013 & 16.46 & 7.56 & 20.38 & 15.34 \\
2014 & 22.73 & 10.2 & 14.76 & 13.24 \\
2015 & 25.54 & 12.86 & 18.55 & 11.88 \\
2016 & 25.36 & 12.25 & 23.55 & 11.18 \\
\hline
\end{tabular}

preceding years. This indicates that either the firm is not converting assets into sales or firm has heavily expanded because of which there is a time lag for reaching economies of scale. In this study, Motorcycles and mopeds category is showing high ratio reflecting intensive use of assets compared to commercial vehicle category.

Table 6 depicts the Z-score for all four categories under Indian automobile industry from 2007 to 2016. Present analysis disclose that Z-score for Motorcycles/Mopeds in range of 5 to 7 . This category under automobile sector is doing substantially well. Z-score for Scooters and 3 -wheelers ranges between 4 to 7 . Even though there is prominent fluctuations, firms have instituted own strategies to compete. The commercial vehicle manufacturers are just on intermediate or grey zone which is frightening situation. 
Table 5. X5 efficiency of using assets to generate sales in percentage

\begin{tabular}{ccccc}
\hline Year & Passenger cars & $\begin{array}{c}\text { Commercial } \\
\text { Vehicles }\end{array}$ & $\begin{array}{c}\text { Motorcycles / } \\
\text { Mopeds }\end{array}$ & $\begin{array}{c}\text { Scooters and } \\
\text { 3-Wheelers }\end{array}$ \\
\hline 2007 & 208.43 & 251.45 & 351.21 & 416 \\
2008 & 175.98 & 201.1 & 318.56 & 327.73 \\
2009 & 169.2 & 105.83 & 306.29 & 276.39 \\
2010 & 210.58 & 114.66 & 379.41 & 295.3 \\
2011 & 231.71 & 131.84 & 384.68 & 328.62 \\
2012 & 224.07 & 158.87 & 376.9 & 334.57 \\
2013 & 223.62 & 132.35 & 380.27 & 271.08 \\
2014 & 207.19 & 110.89 & 430.92 & 229.43 \\
2015 & 199.33 & 110.81 & 414.4 & 223.34 \\
2016 & 194.03 & 130.24 & 395.57 & 203.4 \\
\hline
\end{tabular}

Table 6. Z-score results using Atman's model: 2007 -2016

\begin{tabular}{ccccc}
\hline Year & Passenger cars & $\begin{array}{c}\text { Commercial } \\
\text { Vehicles }\end{array}$ & $\begin{array}{c}\text { Motorcycles / } \\
\text { Mopeds }\end{array}$ & $\begin{array}{c}\text { Scooters and } \\
\text { 3-Wheelers }\end{array}$ \\
\hline 2007 & 3.95 & 4.65 & 5.66 & 4.02 \\
2008 & 3.42 & 3.68 & 5.36 & 4.95 \\
2009 & 2.89 & 2.17 & 5.04 & 4.41 \\
2010 & 3.75 & 2.23 & 6 & 5.56 \\
2011 & 4.07 & 2.5 & 5.54 & 6.69 \\
2012 & 3.75 & 2.77 & 5.81 & 6.24 \\
2013 & 3.69 & 2.22 & 5.81 & 5.34 \\
2014 & 3.25 & 1.84 & 6.76 & 4.8 \\
2015 & 3.36 & 1.6 & 6.58 & 4.58 \\
2016 & 3.23 & 2.02 & 6.17 & 4.68 \\
\hline
\end{tabular}

The reason for variations directly points out at major policy changes in automobile industry especially the ban of diesel vehicles in metropolitan cities. Passenger car manufactures also facing constraints because of policy changes. Nevertheless they have positive because of better monsoon, positive customer sentiments and Seventh Pay Commission bonanza. Also increased competition in the taxi segment has aided to overcome the constraints unlike commercial vehicle category.

\section{Summary and Conclusion}

The study is aimed to examine the financial health of automobile industry in India during Automotive Mission Plan 2006-2016 (AMP 2016) framed by Government of India. The automobile industry has been classified into four categories based on products namely Passenger car, commercial vehicles, motorcy- cle/ mopeds and scooters \& 3-wheelers manufacturers. Altman's Z-score model has been used to assess the performance of each category individually over years starting from 2007 till 2016.

The results reveal that for Motorcycles/Mopeds manufacturers are doing substantially well supported with high demand from middle income group. Scooters and 3-wheelers are facing prominent fluctuations which have constituted own strategies to compete. Both Passenger car and commercial vehicle manufacturers are confronting serious issues since major policy changes in recent years. Especially the ban of diesel vehicles in metropolitan cities has dipped the sales of four wheelers and has forced to hold the final products at warehouses. Passenger car manufacturers are confident to handle situation because of increased competition in the taxi segment ushering more demand unlike commercial vehicle category.

On the contrary, the policy of scrapping older vehicles to meet emissions standards will give new hope to both Passenger and Commercial vehicles category. It is now turn of the firms to make decisions to fully utilize the available capacity. Firms should go for marketing strategy to achieve target sales. Research and development should be given more prominence for adopting new technology for vehicles as well as manufacturing. Innovation is expected in designing new engine technology and alternative fuels. Initiatives to promote eco-friendly vehicles keeping in mind emission norms should also be undertaken simultaneously.

The result is in line with Ray (2011) which provides empirical evidence that $\mathrm{Z}$-score values for automobile industry lies in grey zone. The industry was moving towards gradual inefficiencies since 2007-2008. It draws conclusion that warning signs and $\mathrm{Z}$ score model have the ability to assist management for predicting corporate problems early enough to avoid bankruptcy.

Further research can be conducted on individual firms of each category to understand offsetting effects occurred due to consolidating firms into categories. Probing individual firms in particular industry would give lot of insights to foster ideas in the area of financial distress. 


\section{References}

Agarwal, V., \& Taffler, R. (2008). Comparing the performance of market-based and accounting-based bankruptcy prediction models. Journal of Banking \& Finance, 32(8), 1541-1551. https://doi.org/10.1016/j. jbankfin.2007.07.014

Altman, E. I. (1968). Financial Ratios, Discriminant Analysis and the Prediction of Corporate Bankruptcy. The Journal of Finance, 23(4), 589-609. http://doi.org/10.2307/2978933 https://doi.org/10.1111/j.1540-6261.1968.tb00843.x

Altman, E. I. (I983) Corporate Financial Distress. A Complete Guide to Predicting, Avoiding, and Dealing with Bankruptcy. John Wiley \& Sons, New York.

Altman, E. I., Iwanicz-Drozdowska, M., Laitinen, E. K., \& Suvas, A. (2016). Financial distress prediction in an international context: a review and empirical analysis of altman's Z-score model. Journal of International Financial Management \& Accounting. Retrieved from http://onlinelibrary.wiley.com/doi/10.1111/jifm.12053/ full https://doi.org/10.1111/jifm.12053

Beaver, W. H. (1966). Financial ratios as predictors of failure. Journal of Accounting Research, 71-111. https://doi. org/10.2307/2490171

Bulow, J. I., \& Shoven, J. B. (1978). The bankruptcy decision. The Bell Journal of Economics, 437-456. https:// doi.org/10.2307/3003592

Celli, M. (2015). Can Z-Score Model Predict Listed Companies' Failures in Italy? An Empirical Test. International Journal of Business and Management, 10(3), 57. https://doi.org/10.5539/ijbm.v10n3p57

Chava, S., \& Jarrow, R. A. (2004). Bankruptcy prediction with industry effects. Review of Finance, 8(4), 537-569. https://doi.org/10.1093/rof/8.4.537 https://doi. org/10.1007/s10679-004-6279-6

Chen, H. J., Kacperczyk, M., \& Ortiz-Molina, H. (2012). Do nonfinancial stakeholders affect the pricing of risky debt? Evidence from unionized workers. Review of Finance, 16(2), 347-383. https://doi.org/10.1093/rof/rfq028

Dawkins, M. C., Bhattacharya, N., \& Bamber, L. S. (2007). Systematic share price fluctuations after bankruptcy filings and the investors who drive them. Journal of Financial and Quantitative Analysis, 42(2), 399-419. https://doi.org/10.1017/S002210900000332X

Fich, E. M., \& Slezak, S. L. (2008). Can corporate governance save distressed firms from bankruptcy? An empirical analysis. Review of Quantitative Finance and Accounting, 30(2), 225-251. https://doi.org/10.1007/s11156-007-0048-5

Gilson, S. C. (1989). Management turnover and financial distress. Journal of Financial Economics, 25(2),
241-262. Retrieved From: https://doi.org/10.1016/0304405X(89)90083-4

Grice, J. S., \& Ingram, R. W. (2001). Tests of the generalizability of Altman's bankruptcy prediction model. Journal of Business Research, 54(1), 53-61. Retrieved From: https://doi.org/10.1016/S0148-2963(00)00126-0

John, T. A. (1993). Accounting measures of corporate liquidity, leverage, and costs of financial distress. Financial Management, 91-100. Retrieved From: https://doi. org $/ 10.2307 / 3665930$

Kahya, E., \& Theodossiou, P. (1999). Predicting corporate financial distress: A time-series CUSUM methodology. Review of Quantitative Finance and Accounting, 13(4), 323-345. Retrieved From: https://doi.org/10.1023/A:1008326706404

Kwak, W., Shi, Y., Cheh, J. J., \& Lee, H. (2005). Multiple criteria linear programming data mining approach: An application for bankruptcy prediction. In Data Mining and Knowledge Management (pp. 164-173). Springer. Retrieved from http://link.springer.com/ chapter/10.1007/978-3-540-30537-8_18 Retrieved From: https://doi.org/10.1007/978-3-540-30537-8_18

Li, W. G. (2014). Corporate Financial Distress and Bankruptcy Prediction in the North American Construction Industry. Retrieved from http://econ.duke.edu/uploads/media_ items/ganglidjepaper.original.pdf Moyer

R. C. (1977). Forecasting financial failure: a re-examination. Financial Management, 6(1), 11. Retrieved From: https:// doi.org/10.2307/3665489

Opler, T. C., \& Titman, S. (1994). Financial distress and corporate performance. The Journal of Finance, 49(3), 1015-1040. Retrieved From: https://doi.org/10.1111/ j.1540-6261.1994.tb00086.x

Platt H. D. \& Platt M. B. (2002). Predicting corporate financial distress: reflections on choice-based sample bias. Journal of Economics and Finance, 26(2), 184-199. Retrieved From: https://doi.org/10.1007/BF02755985

Shen, C.-H., Chen, Y. K., \& Huang, B. Y. (2010). The prediction of default with outliers: Robust logistic regression. In Handbook of Quantitative Finance and Risk Management (pp.965-977). Springer. Retrieved from http://link.springer. com/chapter/10.1007/978-0-387-77117-5_62 Retrieved From: https://doi.org/10.1007/978-0-387-77117-5_62

Singhal, R., \& Zhu, Y. E. (2013). Bankruptcy risk, costs and corporate diversification. Journal of Banking \& Finance, 37(5), 1475-1489. Retrieved From: https://doi. org/10.1016/j.jbankfin.2011.11.019

Trieschmann, J. S., \& Pinches, G. E. (1973). A multivariate model for predicting financially distressed PL insurers. Journal of Risk and Insurance, 327-338. Retrieved From: https://doi.org/10.2307/252222 